\title{
Cholinergic Stimulation of Inositol Phosphate Formation in Bovine Adrenal Chromaffin Cells: Distinct Nicotinic and Muscarinic Mechanisms
}

\author{
D. A. Eberhard and R. W. Holz \\ Department of Pharmacology, University of Michigan Medical School, Ann Arbor, Michigan, U.S.A.
}

\begin{abstract}
The ability of cholinergic agonists to activate phospholipase $\mathrm{C}$ in bovine adrenal chromaffin cells was examined by assaying the production of inositol phosphates in cells prelabeled with $\left[{ }^{3} \mathrm{H}\right]$ inositol. We found that both nicotinic and muscarinic agonists increased the accumulation of $\left[{ }^{3} \mathrm{H}\right]$ inositol phosphates (mainly inositol monophosphate) and that the effects mediated by the two types of receptors were independent of each other. The production of inositol phosphates by nicotinic stimulation required extracellular $\mathrm{Ca}^{2+}$ and was maximal at $0.2 \mathrm{mMCa}{ }^{2+}$. Increasing extracellular $\mathrm{Ca}^{2+}$ from 0.22 to $2.2 \mathrm{~m} M$ increased the sensitivity of inositol phosphates formation to stimulation by submaximal concentrations of 1,1-dimethyl-4-phenylpiperazinium iodide (DMPP) but did not enhance the response to muscarine. Elevated $\mathrm{K}^{+}$also stimulated $\mathrm{Ca}^{2+}$-dependent $\left[{ }^{3} \mathrm{H}\right]$ inositol phosphate production, presumably by a non-receptor-mediated mechanism. The $\mathrm{Ca}^{2+}$ channel antagonists D600 and nifedipine inhibited the effects of DMPP and elevated $\mathrm{K}^{+}$to a greater extent than that of muscarine. $\mathrm{Ca}^{2+}(0.3-10 \mu M)$ directly stimulated the release of inositol phosphates from digitonin-permeabilized
\end{abstract}

cells that had been prelabeled with $\left[{ }^{3} \mathrm{H}\right]$ inositol. Thus, cholinergic stimulation of bovine adrenal chromaffin cells results in the activation of phospholipase $\mathrm{C}$ by distinct muscarinic and nicotinic mechanisms. Nicotinic receptor stimulation and elevated $\mathrm{K}^{+}$probably increased the accumulation of inositol phosphates through $\mathrm{Ca}^{2+}$ influx and a rise in cytosolic $\mathrm{Ca}^{2+}$. Because $\mathrm{Ba}^{2+}$ caused catecholamine secretion but did not enhance the formation of inositol phosphates, phospholipase $\mathrm{C}$ activation is not required for exocytosis. However, diglyceride and myo-inositol 1,4,5-trisphosphate produced during cholinergic stimulation of chromaffin cells may modulate secretion and other cellular processes by activating protein kinase $\mathrm{C}$ and/or releasing $\mathrm{Ca}^{2+}$ from intracellular stores. Key Words: Chromaffin cells-Nicotinic agonist-Muscarinic agonistPhospholipase C-Inositol phosphates-Catecholamine secretion. Eberhard D. A. and Holz R. W. Cholinergic stimulation of inositol phosphate formation in bovine adrenal chromaffin cells: Distinct nicotinic and muscarinic mechanisms. J. Neurochem. 49, 1634-1643 (1987).
Exocytosis of catecholamine from bovine adrenal medulla is normally triggered by nicotinic receptorinduced influx of extracellular $\mathrm{Ca}^{2+}$ and a rise in cytosolic $\mathrm{Ca}^{2+}$ (Douglas, 1975; Holz et al., 1982; Kilpatrick et al., 1982; Knight and Kesteven, 1983; Kao and Schneider, 1986). Depolarization by elevated $\mathrm{K}^{+}$ also induces $\mathrm{Ca}^{2+}$ influx, and a rise in cytosolic $\mathrm{Ca}^{2+}$ and catecholamine secretion. In many secretory systems exocytosis is associated with a receptor-mediated increase of phospholipase $\mathrm{C}$ activity that results in increased turnover of phosphatidylinositol (PI) and phosphatidate (see Nishizuka, 1984 for re- view). In bovine chromaffin cells acetylcholine increases the turnover of PI and phosphatidate (Trifaro, 1969). This effect was found to be mediated mainly through muscarinic receptor activation (Fisher et al., 1981; Adnan and Hawthorne, 1981) which does not stimulate secretion (Wilson and Kirshner, 1977). However, nicotinic stimulation caused small and sporadic increases in PI and phosphatidate turnover which were not characterized (Fisher et al., 1981).

More recently it was discovered that two products of the phospholipase $C$ reaction, diglyceride and myo-inositol 1,4,5-trisphosphate $\left(\mathrm{IP}_{3}\right)$, can affect se-
Received April 8, 1987; revised manuscript received June 19, 1987; accepted June 22, 1987.

Address correspondence to Dr. R. W. Holz at Department of Pharmacology, University of Michigan Medical School, M6322 Medical Science I, Ann Arbor, MI 48109-0626, U.S.A.

Abbreviations used: DMPP, 1,1-dimethyl-4-phenylpiperazinium iodide; HEPES, $N$-2-hydroxyethylpiperazine- $N^{\prime}$-2-ethanesulfonic acid; IP, myo-inositol 1-phosphate; $\mathrm{IP}_{2}$, myo-inositol 1,4-bisphosphate; $\mathrm{IP}_{3}$, myo-inositol 1,4,5-trisphosphate; PI, phosphatidylinositol; PIPES, piperazine- $N, N^{\prime}$-bis(2-ethanesulfonic acid); PSS, physiological salt solution; TCA, trichloroacetic acid. 
cretion in different ways. Diglyceride activates the $\mathrm{Ca}^{2+}$, phospholipid-dependent enzyme protein kinase C (Nishizuka, 1984) which stimulates exocytosis in secretory cells including adrenal chromaffin cells (Knight and Baker, 1983; Pocotte et al., 1985). IP causes the release of $\mathrm{Ca}^{2+}$ from intracellular stores in many cells (Berridge and Irvine, 1984) including chromaffin cells (Stoehr et al., 1986). By measuring the production of inositol phosphates, which are the immediate products of phospholipase $\mathrm{C}$ activity (Agranoff et al., 1983; Berridge et al., 1983; Putney et al., 1983), we have reinvestigated the possible activation of phospholipase $\mathrm{C}$ by various secretagogues.

Studies were performed with both intact chromaffin cells and digitonin-permeabilized chromaffin cells. We found that nicotinic stimulation and elevated $\mathrm{K}^{+}$as well as muscarinic stimulation cause accumulation of inositol phosphates in intact cells, and that micromolar concentrations of $\mathrm{Ca}^{2+}$ directly stimulate the release of inositol phosphates from permeabilized cells.

\section{MATERIALS AND METHODS}

Chromaffin cells were isolated by dissociation of bovine adrenal medullae, purified by differential plating (Waymire et al., 1983), and cultured as monolayers in $6.4 \mathrm{~mm}$ diameter collagen coated wells, 150,000 cells/well as previously described by Holz et al. (1982). The cultures were at least 90\% chromaffin cells (Waymire et al., 1983), and contained virtually no visually detectable fibroblasts or endothelial cells.

Experiments were performed 4-14 days after culture preparation. Inositol lipids were labeled with $\left[{ }^{3} \mathrm{H}\right]$ inositol by replacing the culture medium with $m y o-\left[{ }^{3} \mathrm{H}\right]$ inositol (0.6-1.2 $\mu M, 15 \mathrm{Ci} / \mathrm{mmol})$ in physiological salt solution (PSS) containing $145 \mathrm{mM} \mathrm{NaCl}, 5.6 \mathrm{~m} M \mathrm{KCl}, 2.2 \mathrm{~m} M$ $\mathrm{CaCl}_{2}, 0.5 \mathrm{~m} M \mathrm{MgCl}_{2}, 5.6 \mathrm{~m} M$ glucose, $0.5 \mathrm{~m} M$ ascorbic acid, and $15 \mathrm{~m} M N$-2-hydroxyethylpiperazine- $N^{\prime}$-2-ethanesulfonic acid (HEPES), pH 7.4. For longer labeling pe- riods $\left(12-48 \mathrm{~h}\right.$ ) cells were incubated with myo- $\left[{ }^{3} \mathrm{H}\right]$ inositol in Dulbecco's minimal essential medium (MEM), free of unlabeled inositol and supplemented with $15 \mathrm{~m} M$ HEPES, at $34^{\circ} \mathrm{C}$ in $5 \% \mathrm{CO}_{2}$ atmosphere.

Experiments were performed at $25^{\circ} \mathrm{C}$. The cells were washed for 5-10 min with PSS containing $10 \mathrm{~m} M \mathrm{LiCl}$ to inhibit inositol phosphate phosphatase (Berridge et al., 1982). The solution was replaced with PSS $(100 \mu 1)$ containing $10 \mathrm{~m} M \mathrm{LiCl}$, with or without drugs. Incubations were terminated by addition of $10 \%$ tricholoroacetic acid (TCA) $(100 \mu \mathrm{l})$. After $\mathrm{l}-2 \mathrm{~h}$ on ice, the contents of the wells were transferred to conical $1.5-\mathrm{ml}$ polypropylene tubes containing $100 \mu \mathrm{l}$ ice-cold $10 \%$ TCA. The wells were washed with $100 \mu \mathrm{l}, 1 \mathrm{mg} / \mathrm{ml}$ bovine serum albumin (as carrier protein) which was added to the incubation solutions to bring the final TCA concentration to $5 \%$. The tubes were centrifuged $5 \mathrm{~min}$ in an Eppendorf microfuge at $4^{\circ} \mathrm{C}$. Supernatants were transferred to $10 \times 75 \mathrm{~mm}$ test tubes on ice, extracted three times with $1.5-2.0 \mathrm{ml}$ diethyl ether, and neutralized with $0.01 \mathrm{M} \mathrm{NaOH}$ (final $\mathrm{pH}$ 6.5-8.0). The samples were stored refrigerated overnight before measuring the inositol phosphates.

Experiments using permeabilized cells were performed by incubating $\left[{ }^{3} \mathrm{H}\right]$ inositol-prelabeled cells with a solution (KGEP) containing $139 \mathrm{mM}$ potassium glutamate, $20 \mathrm{mM}$ 1,4-piperazinediethanesulfonic acid (PIPES, pH 6.6), 2 $\mathrm{m} M$ MgATP, $20 \mu M$ digitonin, $5 \mathrm{~m} M$ EGTA, and various amounts of $\mathrm{Ca}^{2+}$ to achieve free $\mathrm{Ca}^{2+}$ concentrations calculated according to Portzehl et al. (1964). The incubations were terminated by adding TCA and samples were processed as described above. $\left[{ }^{3} \mathrm{H}\right]$ Inositol phosphates were separated by anion-exchange chromatography according to Berridge et al. (1982, 1983). Samples were applied to freshly poured columns of Dowex AG1- $\times 8$ (formate form), $0.2 \mathrm{ml}$ bed volume. Free inositol was eluted with $8 \times 0.5 \mathrm{ml}$ washes of $\mathrm{H}_{2} \mathrm{O}$ and usually discarded. $\left[{ }^{3} \mathrm{H}\right]$ Inositol phosphates were sequentially eluted by eight additions of $0.3 \mathrm{ml}$ of each of the following solutions: $5 \mathrm{~m} M \mathrm{Na}$ borate $/ 60 \mathrm{~m} M$ Na formate (glycerophosphoinositol), $0.2 \mathrm{M}$ ammonium formate/0.1 $M$ formic acid [myo-inositol 1 -monophosphate (IP)], $0.4 \mathrm{~m} \mathrm{M} \mathrm{NH}$ formate $^{2} 0.1 M$ formic acid [myoinositol 1,4-bisphosphate $\left.\left(\mathrm{IP}_{2}\right)\right]$, and $1 M \mathrm{NH}_{4}$ formate/0.1 $M$ formic acid ( $\left.\mathrm{IP}_{3}\right)$ (Berridge et al., 1983). Total inositol

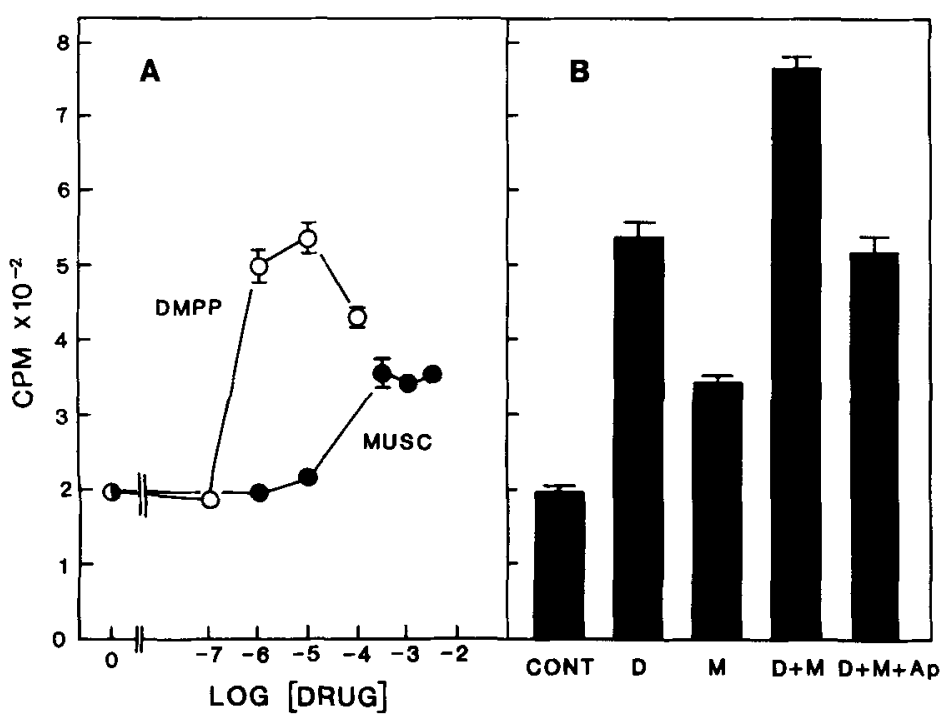

FIG. 1. Effects of various concentrations of muscarine and DMPP on the accumulation of inositol phosphates. A: Cells prelabeled for $3 \mathrm{~h}$ in $\left[{ }^{3} \mathrm{H}\right]$ inositol were incubated for $6 \mathrm{~min}$ in $10 \mathrm{mM} \mathrm{LiCl}$. Cells were subsequently incubated in PSS containing $10 \mathrm{mM} \mathrm{LiCl}$ and no drug or various concentrations of muscarine (MUSC) or DMPP. After $\mathbf{3 0}$ min the amount of $\left[{ }^{3} \mathrm{H}\right]$ inositol phosphates in cells was determined. $B:\left[{ }^{3} \mathrm{H}\right]$ lnositol-labeled cells were incubated for 30 min without drug (CONT), in $1 \mathrm{mM}$ muscarine (M), in $10 \mu M$ DMPP (D), in $1 \mathrm{mM}$ muscarine $+10 \mu M$ DMPP, or in $1 \mathrm{mM}$ muscarine + $10 \mu \mathrm{M}$ DMPP $+2 \mu M$ atropine (Ap). The data in $B$ were from the same experiment in $A$. There were four wells/group. In B all drug-containing groups were significantly different from the control $(p<0.01)$. 


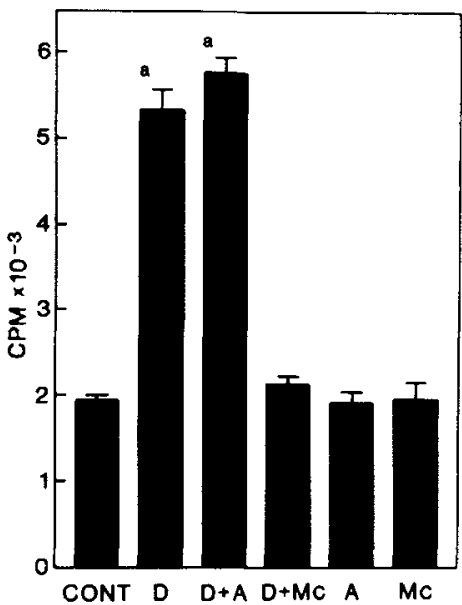

FIG. 2. Effects of cholinergic antagonists on DMPP-induced accumulation of inositol phosphates. Cells prelabeled for $18 \mathrm{~h}$ with $\left[{ }^{3} \mathrm{H}\right]$ inositol were incubated for $7 \mathrm{~min}$ in PSS containing $10 \mathrm{mM}$ $\mathrm{LiCl}$ and no drug, $1 \mu \mathrm{M}$ atropine, or $1 \mu \mathrm{M}$ mecamylamine. Cells were subsequently incubated for $30 \mathrm{~min}$ in PSS containing $10 \mathrm{mM}$ $\mathrm{LiCl}$ and no drug (CONT), $10 \mu \mathrm{M}$ DMPP (D), $10 \mu \mathrm{M}$ DMPP, and 1 $\mu M$ atropine (D + A), $10 \mu M$ DMPP and $1 \mu M$ mecamylamine (D $+\mathrm{MC}$ ), $1 \mu M$ atropine (A), or $1 \mu M$ mecamylamine (Mc). There were four wells/group. ${ }^{a} \mathrm{p}<0.01$ versus CONT.

phosphates were eluted with eight additions of $0.3 \mathrm{ml} 1 \mathrm{M}$ $\mathrm{NH}_{4}$ formate/0.1 $M$ formic acid, after the $5 \mathrm{mM} \mathrm{Na}$ borate $/ 60 \mathrm{~m} M \mathrm{Na}$ formate wash. Radioactivity in the effluent was determined by scintillation counting. Values are expressed as average cpm/well \pm SEM. Error bars smaller than the point symbols were omitted. Differences between means of groups were tested for significance with Student's $t$ test.

Catecholamine secretion was measured by prelabeling catecholamine stores in chromaffin cells with $\left[{ }^{3} \mathrm{H}\right]-$ norepinephrine and measuring the release of $\left[{ }^{3} \mathrm{H}\right]-$ norepinephrine as previously described by Kilpatrick et al., (1982) and Dunn and Holz (1983).

\section{Materials}

All reagents were obtained from standard commercial sources. $m y o-\left[{ }^{3} \mathrm{H}\right]$ Inositol $(1 \mathrm{mCi} / \mathrm{ml})$ was from Amersham Corporation (Arlington Heights, IL, U.S.A.) or from American Radiolabelled Chemicals (St. Louis, MO, U.S.A.). Polar contaminants were removed before use by mixing a few milligrams of Dowex AGl- $\times 8$ with aqueous myo- $\left[{ }^{3} \mathrm{H}\right]-$ inositol. The resin was removed by centrifugation and washed with $\mathrm{H}_{2} \mathrm{O} .\left[{ }^{3} \mathrm{H}\right]$ Norepinephrine was from New England Nuclear Corporation (Boston, MA, U.S.A.).

\section{RESULTS}

\section{Cholinergic pharmacology of $\left[{ }^{3} \mathrm{H}\right]$ inositol phosphates production}

Incubation of $\left[{ }^{3} \mathrm{H}\right]$ inositol-prelabeled chromaffin cells with muscarine or 1,1-dimethyl-4-phenylpiperazinium iodide (DMPP) in the presence of $10 \mathrm{mM}$ $\mathrm{LiCl}$ enhanced the accumulation of $\left[{ }^{3} \mathrm{H}\right]$ inositol phosphates (Fig. 1). The response to these drugs was concentration dependent and maximal at $0.3 \mathrm{~m} M$ muscarine and 1-10 $\mu M$ DMPP (Fig. 1A). The effects of DMPP $(10 \mu M)$ and muscarine $(1.0 \mathrm{~m} M)$ were additive at concentrations that for each alone caused maximal effects (Fig. 1B). The presence of atropine (2 $\mu M$ ) together with DMPP and muscarine reduced inositol phosphate accumulation to that produced by DMPP alone. In similar experiments, the accumulation of inositol phosphates produced by the mixed nicotinic-muscarinic agonist carbachol was approximately the sum of the effects produced by DMPP and muscarine (data not shown). The effect of carbachol was only partially blocked by either $1 \mu M$ atropine (60\% inhibition) or $1 \mu M$ mecamylamine (44\% inhibition).

The ability of muscarine to stimulate the formation of inositol phosphates was anticipated because of previous studies that demonstrated muscarinic stim-

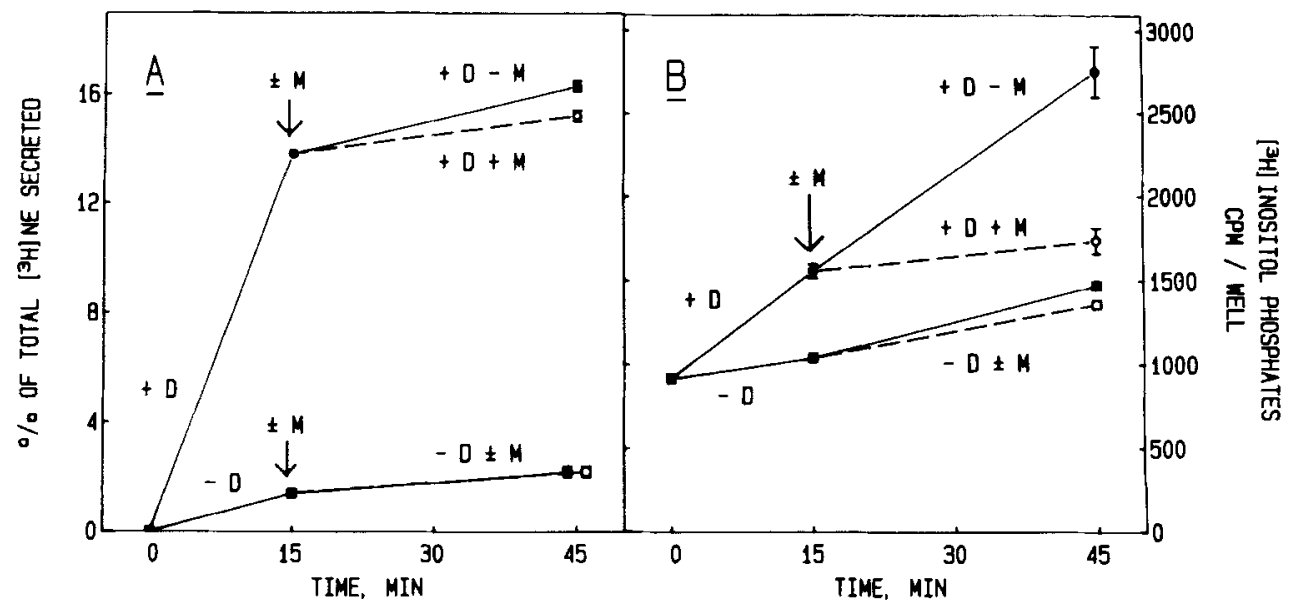

FIG. 3. Effect of adding mecamylamine (M) after DMPP (D)-stimulated secretion is complete, on the subsequent accumulation of inositol phosphates. Cells prelabeled $6 \mathrm{~h}$ with $\left[{ }^{3} \mathrm{H}\right]$ norepinephrine (A) or $16 \mathrm{~h}$ with $\left[{ }^{3} \mathrm{H}\right]$ inositol (B) were incubated in $50 \mu$ l PSS with (circles) or without (squares) $10 \mu M$ DMPP. After $15 \mathrm{~min}$, either the incubations were terminated or $150 \mu \mathrm{l}$ PSS with or without DMPP (final concentration $10 \mu M$ ) and with (open symbols) or without (closed symbols) mecamylamine (final concentrations $3 \mu M$ ), was added. The incubations were continued another $30 \mathrm{~min}$ before determining $\left[{ }^{3} \mathrm{H}\right]$ norepinephrine release or $\left[{ }^{3} \mathrm{H}\right]$ inositol phosphates accumulation. There were four wells/group. 
ulation of phosphatidylinositol and phosphatidate metabolism (Fisher et al., 1981; Adnan and Hawthorne, 1981). However, a response to a selective nicotinic agonist was not predicted. The pharmacology of the DMPP-induced inositol phosphates production was investigated with selective cholinergic antagonists (Fig. 2). The response to DMPP was completely blocked by the specific nicotinic antagonist mecamylamine $(1 \mu M)$, but was unaffected by atropine at a concentration that selectively blocks muscarinic receptors $(1 \mu M)$. Thus, nicotinic as well as muscarinic receptor stimulation increased the production of inositol phosphates.

Nicotinic stimulation of bov'ne chromaffin cells results in the secretion of a number of substances including epinephrine, norepinephrine, ATP, enkephalins, and proteins. To investigate whether a secreted substance was responsible for the stimulated production of inositol phosphates by DMPP, chromaffin cells were incubated with DMPP for $15 \mathrm{~min}$ by which time catecholamine secretion was nearly complete (Fig. 3A). Additional medium containing $10 \mu M$ DMPP and/or $3 \mu M$ mecamylamine was then added and the incubations continued for $30 \mathrm{~min}$. Mecamylamine added at 15 min completely blocked the subsequent accumulation of inositol phosphates (Fig. 3B), indicating that DMPP itself, rather than a substance coreleased with $\left[{ }^{3} \mathrm{H}\right]$ norepinephrine prior to the addition of mecamylamine, was responsible for the effect. Further evidence that secreted substances did not increase the accumulation of inositol phosphates was provided by two other experiments. In one experiment, chromaffin cells were incubated with DMPP for $20 \mathrm{~min}$. The medium was then transferred to wells containing cells that had been prelabeled with $\left[{ }^{3} \mathrm{H}\right]$ inositol and the cells were incubated for $30 \mathrm{~min}$. Mecamylamine $(1 \mu M)$ was added to block the direct effects of DMPP in the medium. $\left[{ }^{3} \mathrm{H}\right]$ Inositol phosphates production was not stimulated under these conditions (data not shown). In another experiment, chromaffin cells were incubated with or without DMPP in various volumes of medium. Increasing the volume of the medium should dilute a hypothetical stimulator of phospholipase C which is released during secretion and thereby decrease the accumulation of inositol phosphates. The DMPP-stimulated formation of inositol phosphates was not affected by variations in the volume of incubation medium over the entire range examined, 40-300 $\mu$ l (data not shown).

\section{Time courses of accumulation of $\left[^{3} \mathrm{H}\right]$ inositol phosphates}

The time courses of the accumulation of inositol phosphates in response to DMPP and muscarine were investigated (Fig. 4). IP, $\mathrm{IP}_{2}$, and $\mathrm{IP}_{3}$ were all increased by both nicotinic and muscarinic stimulation in the presence of $10 \mathrm{mM} \mathrm{LiCl}$. DMPP induced a rapid elevation of $\mathrm{IP}_{3}$ and $\mathrm{IP}_{2}$ within the first 2 min.

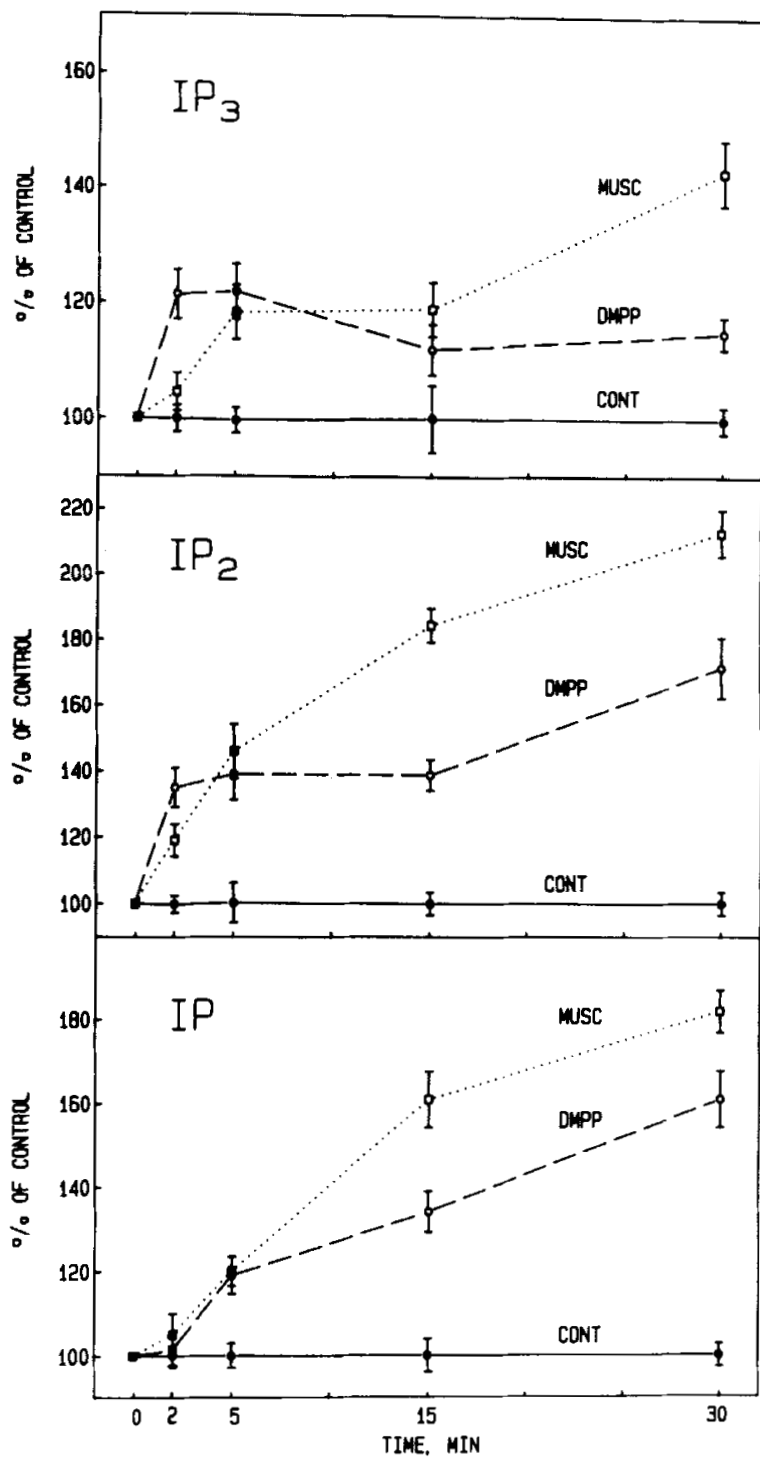

FIG. 4. Time course of muscarine and DMPP-induced production of $\left[{ }^{3} \mathrm{H}\right]$ inositol phosphates. Cells prelabeled with $\left[{ }^{3} \mathrm{H}\right]$ inositol were preincubated $5 \mathrm{~min}$ in $40 \mu \mathrm{l}$ PSS with $10 \mathrm{mM} \mathrm{LiCl}$. One hundred and twenty microliters of PSS containing $10 \mathrm{mM} \mathrm{LiCl}$ and no drug (CONT, ), DMPP $10 \mu M$ final concentration (O), or muscarine (MUSC) $0.3 \mathrm{mM}$ final concentration ( $\square$ ) was then added at zero time. At the indicated times, the amounts radioactive $I P, I P_{2}$, and $\mathrm{IP}_{3}$ levels were determined. The figure shows the combined results from four experiments. The data are expressed as the percent of control at each time point \pm SEM. There were 16 samples/ data point (four samples/group in each of four experiments). In two of the experiments, the $\left[{ }^{3} \mathrm{H}\right]$ inositol activity incorporated into lipid was also measured. At zero time, the $\mathrm{cpm} / 1 \mathrm{O}^{4} \mathrm{cpm}\left[{ }^{3} \mathrm{H}\right]$ lipid were: IP, 550 and 340; $\mathrm{IP}_{2}, 57$ and 25; IP, 62 and 19.

The accumulation of $\mathrm{IP}_{3}$ and $\mathrm{IP}_{2}$ in the presence of muscarine occurred more slowly initially but was more sustained, surpassing the nicotinic effect after 5 min. The elevations in $\mathrm{IP}_{3}$ and $\mathrm{IP}_{2}$ produced by both DMPP and muscarine persisted through $30 \mathrm{~min}$. IP accumulation in response to DMPP and muscarine was not evident until $5 \mathrm{~min}$ and continued through 
$30 \mathrm{~min}$. With both agonists, the slower production of IP is consistent with a phosphodiesteratic cleavage of PI bisphosphate and perhaps PI phosphate, and a subsequent dephosphorylation of $\mathrm{IP}_{3}$ and $\mathrm{IP}_{2}$ to form IP. No consistent accumulation of glycerophosphoinositol was observed. In nonstimulated cells $80-90 \%$ of the total $\left[{ }^{3} \mathrm{H}\right]$ inositol phosphates activity recovered was present as IP. The remaining radioactivity consisted of approximately equal amounts of $\mathrm{IP}_{3}$ and $\mathrm{IP}_{2}$.

\section{Ability of elevated $\mathrm{K}^{+}$and $\mathrm{Ba}^{2+}$ to stimulate the accumulation of inositol phosphates}

The effects of noncholinergic stimulators of exocytosis on inositol phosphate accumulation in chromaffin cells were investigated (Table 1). Depolarization induced by elevated $\mathrm{K}^{+}$, which stimulates $\mathrm{Ca}^{2+}$ influx, increased the production of inositol phosphates similarly to DMPP. The effect of elevated $\mathrm{K}^{+}$ was completely inhibited in $\mathrm{Ca}^{2+}$-free medium containing $1 \mathrm{~m} M$ EGTA under conditions identical to those described in the footnote to Table 2 (data not shown). Thus, stimulation of chromaffin cells through a mechanism not involving specific cell surface receptors induced the accumulation of inositol phosphates.

$\mathrm{Ba}^{2+}$, a potent stimulator of catecholamine secretion, did not cause a detectable increase of inositol phosphates (Table 1). $\mathrm{Ba}^{2+} 2.2 \mathrm{mM}$ in the absence of $\mathrm{Ca}^{2+}$ completely inhibited the muscarinic stimulation of inositol phosphates accumulation (data not shown). Thus, $\mathrm{Ba}^{2+}$ not only fails to activate phospholipase $\mathrm{C}$ directly but also interferes with the capacity of another stimulus to activate phospholipase $\mathrm{C}$.

TABLE 1. Effects of various secretagogues on the accumulation of inositol phosphates and on catecholamine secretion in adrenal chromaffin cells

\begin{tabular}{lcc}
\hline & $\begin{array}{c}{\left[{ }^{3} \mathrm{H}\right] \text { Inositol }} \\
\text { phosphates } \\
(\mathrm{cpm})\end{array}$ & $\begin{array}{c}\left.{ }^{3} \mathrm{H}\right] \text { Norepinephrine } \\
\text { secretion }\end{array}$ \\
\hline No addition & $936 \pm 20$ & $5.5 \pm 0.2$ \\
Carbachol $(0.3 \mathrm{~m} M)$ & $4,043 \pm 527^{a}$ & $14.4 \pm 0.2^{b}$ \\
DMPP $(10 \mu M)$ & $1,915 \pm 85^{a}$ & $16.3 \pm 0.1^{b}$ \\
$\mathrm{~K}^{+}(56 \mathrm{~m} M)$ & $2,149 \pm 95^{a}$ & $15.7 \pm 0.3^{b}$ \\
$\mathrm{Ba}^{2+}(2.2 \mathrm{~m} M)$ & $1,006 \pm 27$ & $49.1 \pm 1.8^{b}$ \\
\hline
\end{tabular}

Cells prelabeled for $19 \mathrm{~h}$ in $\left[{ }^{3} \mathrm{H}\right]$ inositol or for $3 \mathrm{~h}$ in $\left[{ }^{3} \mathrm{H}\right]$ norepinephrine were incubated for $6 \mathrm{~min}$ in PSS with $10 \mathrm{mMLiCl}$. Cells were subsequently incubated in the continuing presence of $10 \mathrm{mM}$ $\mathrm{LiCl}$ with various secretagogues for $30 \mathrm{~min}$ and the accumulation of $\left[{ }^{3} \mathrm{H}\right]$ inositol phosphates or the secretion of $\left[{ }^{3} \mathrm{H}\right]$ norepinephrine was measured. $\mathrm{Ca}^{2+}$ was omitted from medium containing $\mathrm{Ba}^{2+}$ Osmolality was maintained in the presence of $56 \mathrm{mM} \mathrm{KCl}$ by reducing the $\mathrm{NaCl}$ concentration from $145 \mathrm{~m} M$ to $95 \mathrm{mM}$. There were four wells/group.

${ }^{a} \mathrm{p}<0.01$ versus no addition.

${ }^{b} \mathrm{p}<0.001$ versus no addition.
TABLE 2. Inhibition by $\mathrm{Ca}^{2+}$-free medium of muscarineand DMPP-induced accumulation of inositol phosphates

\begin{tabular}{llr}
\hline & \multicolumn{2}{c}{$\begin{array}{c}\text { Percent inhibition } \\
\text { compared to stimulation } \\
\text { in } 2.2 \mathrm{~m} M \mathrm{Ca}^{2+}\end{array}$} \\
\cline { 2 - 3 } Incubation condition & Muscarine & DMPP \\
\hline $0 \mathrm{Ca}^{2+}$ & $42 \pm 5$ & $67 \pm 7$ \\
$0 \mathrm{Ca}^{2+}+1 \mathrm{~m} M$ EGTA & $83 \pm 4$ & $117 \pm 8$ \\
\hline
\end{tabular}

Muscarine- or DMPP-induced accumulation of inositol phosphates were compared in the presence or absence of $\mathrm{Ca}^{2+}$. Chromaffin cells were rapidly washed with medium containing $2.2 \mathrm{mM}$ $\mathrm{Ca}^{2+}, 0 \mathrm{Ca}^{2+}$, or $0 \mathrm{Ca}^{2+}(+1 \mathrm{mM}$ EGTA). The wash was immediately replaced with fresh medium containing the same concentration of $\mathrm{Ca}^{2+} /$ EGTA and no drug, $0.3 \mathrm{mM}$ muscarine, or $10 \mu \mathrm{M}$ DMPP. Total $\left[{ }^{3} \mathrm{H}\right]$ inositol phosphates were determined after either $6 \mathrm{~min}$ (three experiments) or $30 \mathrm{~min}$ (three experiments). Similar results were obtained at both time points. The data in the table are expressed as the average inhibition caused by the absence of $\mathrm{Ca}^{2+}$ in six experiments \pm the standard error of the mean among the experiments. In each experiment, there were three or four samples/ group. In every experiment, removal of $\mathrm{Ca}^{2+}$ caused a greater inhibition of the DMPP-induced accumulation of inositol phosphates than of the muscarinic effect.

\section{$\mathrm{Ca}^{2+}$ dependencies of DMPP- and muscarine- induced accumulation of inositol phosphates}

The effect of removal of extracellular $\mathrm{Ca}^{2+}$ on the accumulation of total inositol phosphates in the presence of DMPP or muscarine was investigated (Table 2). The amounts of inositol phosphates produced by both agonists were decreased when the $\mathrm{Ca}^{2+}$ in the medium was reduced from $2.2 \mathrm{mM}$ to $0 \mathrm{Ca}^{2+}$ in the absence of EGTA and inhibited further by the inclusion of EGTA. The removal of $\mathrm{Ca}^{2+}$ inhibited the effect of DMPP to a greater extent than that of muscarine. When $1 \mathrm{~m} M$ EGTA was included in the incubation medium, the amount of intracellular inositol phosphates in the presence of DMPP was reduced to below the level in the absence of drug (inhibition $>100 \%$, Table 1; six out of six experiments). Inclusion of EGTA in $\mathrm{Ca}^{2+}$-free medium only in a rapid wash immediately before the addition of drug in $\mathrm{Ca}^{2+}$-free medium without EGTA was still sufficient to abolish the effect of DMPP and to reduce the effects of muscarine.

The effect of varying the concentration of extracellular $\mathrm{Ca}^{2+}$ on the responses to DMPP and muscarine was examined. The effects of both $10 \mu M$ DMPP and $0.3 \mathrm{~m} M$ muscarine were submaximal at $0.1 \mathrm{~m} M \mathrm{Ca}^{2+}$ and maximal at $0.2 \mathrm{mMC \textrm {Ca } ^ { 2 + }}$ (data not shown). However, changing the $\mathrm{Ca}^{2+}$ concentration affected the dose-response curves of DMPP and muscarine in different ways (Fig. 5). Increasing extracellular $\mathrm{Ca}^{2+}$ from $0.22 \mathrm{~m} M$ to $2.2 \mathrm{mM}$ enhanced the accumulation of inositol phosphates induced by submaximal concentrations of DMPP $(0.6-1.5 \mu M$, Fig. 5A). In contrast, raising extracellular $\mathrm{Ca}^{2+}$ did not enhance the response to muscarine (Fig. 5B). The basal accu- 

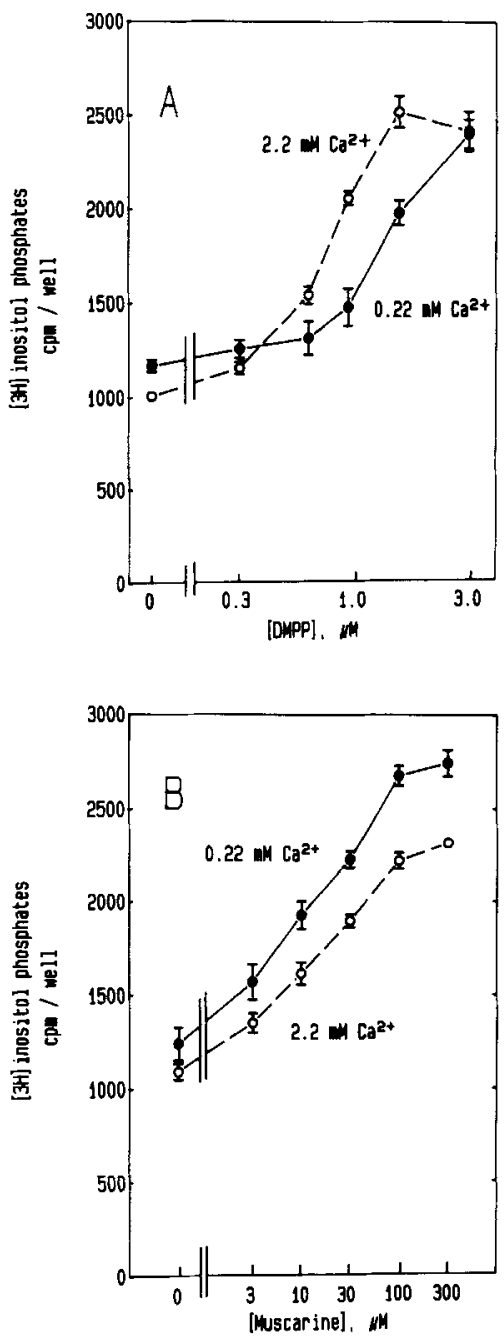

FIG. 5. Effect of $\left[\mathrm{Ca}^{2+}\right]$ on the concentration-effect relationships for DMPP and muscarine. Cells prelabeled with $\left[{ }^{3} \mathrm{H}\right]$ inositol were incubated in PSS containing $10 \mathrm{mM} \mathrm{LiCl}, 0.22 \mathrm{mM} \mathrm{Ca}^{2+}(\bullet)$, or 2.2 $\mathrm{mM} \mathrm{Ca}{ }^{2+}(O)$, and various concentrations of DMPP (A) or muscarine (B). After $45 \mathrm{~min}$ the amount of inositol phosphates in the wells were determined. There were four wells/group.

mulation of inositol phosphates was somewhat reduced by increasing extracellular $\mathrm{Ca}^{2+}$.

Effects of $\mathrm{Ca}^{2+}$ channel antagonists on the stimulated production of inositol phosphates

D600 (methoxyverapamil) blocks $\mathrm{Ca}^{2+}$ influx and catecholamine secretion induced by nicotinic stimulation or depolarization (Pinto and Trifaro, 1976; Corcoran and Kirshner, 1983). Dihydropyridines also inhibit catecholamine secretion induced by nicotinic agonists as well as depolarization (Cena et al., 1983; Boarder et al., 1987). The effects of D600 and nifedipine were examined to determine whether the stimulated production of inositol phosphates by muscarine, DMPP, and elevated $\mathrm{K}^{+}$requires $\mathrm{Ca}^{2+}$ entry into the cells (Fig. 6). The effects of both DMPP and elevated $\mathrm{K}^{+}$were inhibited over $50 \%$ by $3 \mu \mathrm{M}$
D600 and virtually abolished by $30 \mu M$ D600 (Fig. 6A). In contrast, the muscarine-stimulated accumulation of $\left[{ }^{3} \mathrm{H}\right]$ inositol phosphates was not inhibited by $3 \mu M$ D600 and inhibited only $35 \%$ by $30 \mu M$ D 600 . Nifedipine at $1 \mu M$ inhibited the effects of DMPP and elevated $\mathrm{K}^{+}$by nearly $50 \%$ but did not inhibit the muscarinic response (Fig. 6B).

Effects of micromolar $\mathrm{Ca}^{2+}$ on the production of inositol phosphates in digitonin-permeabilized chromaffin cells

Digitonin-treated chromaffin cells are permeable to $\mathrm{Ca}^{2+}$, ATP, and proteins (Dunn and Holz, 1983; Wilson and Kirshner, 1983). In cells permeabilized with digitonin, secretory granule function is normal
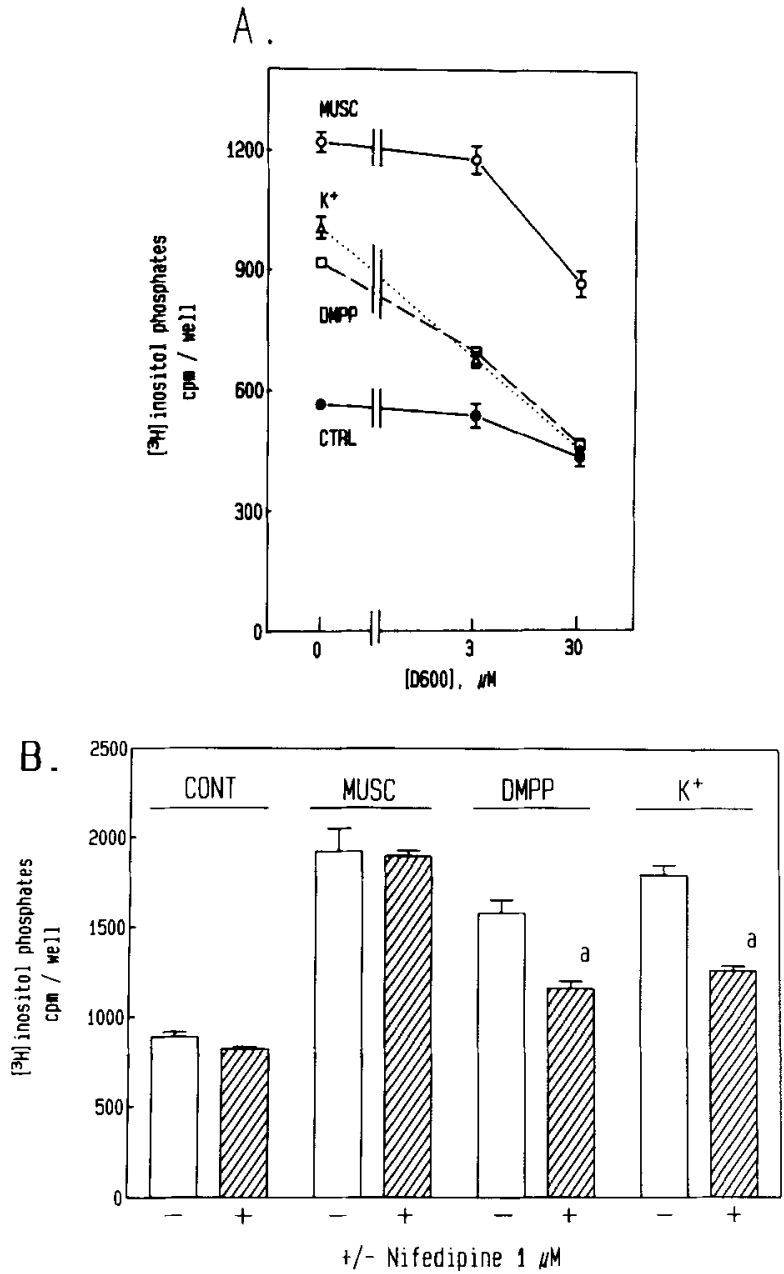

FIG. 6. Effects of $\mathrm{Ca}^{2+}$ channel antagonists on the stimulated formation of inositol phosphates. Cells were prelabeled with $\left[{ }^{3} \mathrm{H}\right]-$ inositol, washed, and incubated $30 \mathrm{~min}$ in PSS $\left(0.22 \mathrm{mM} \mathrm{Ca}^{2+}, 10\right.$ $\mathrm{mM}$ LiCl) containing: (A) no addition (CTRL, $\bullet$ ), $300 \mu M$ muscarine (MUSC, O), $3 \mu M$ DMPP ( $\square$ ), or $56 \mathrm{mM} \mathrm{K}(\triangle)$, with the indicated concentrations of D600; (B) no addition (CONT), $300 \mu \mathrm{M}$ muscarine (MUSC), $3 \mu M$ DMPP (DMPP), or $56 \mathrm{mM}\left(\mathrm{K}^{+}\right)$, with $0.01 \%$ dimethyl sulfoxide and with (shaded bars) or without (open bars) 1 $\mu M$ nifedipine. There were four wells/group. ${ }^{2} p<0.01$ versus stimulation in the absence of nifedipine. 
and micromolar $\mathrm{Ca}^{2+}$ in the presence of $\mathrm{MgATP}$ directly stimulates exocytosis of catecholamine (Dunn and Holz, 1983; Wilson and Kirshner, 1983; Holz and Senter, 1985). To investigate the direct effects of micromolar $\mathrm{Ca}^{2+}$ on the intracellular mechanisms responsible for production of inositol phosphates, cells prelabeled with $\left[{ }^{3} \mathrm{H}\right]$ inositol were permeabilized with digitonin in the presence of MgATP and various concentrations of $\mathrm{Ca}^{2+}$ (Fig. 7). The production of inositol phosphates was found to be dependent on the concentration of $\mathrm{Ca}^{2+}$ in the submicromolar to micromolar range.

\section{DISCUSSION}

Nicotinic as well as muscarinic receptor activation stimulates the accumulation of inositol phosphates

In a previous study we found that muscarinic stimulation increased $\left[{ }^{3} \mathrm{H}\right]$ glycerol and $\left[{ }^{32} \mathrm{P}\right]$ phosphate incorporation into phosphatidylinositol and phosphatidate (Fisher et al., 1981). Muscarinic stimulation of $\left[{ }^{32} \mathrm{P}\right]$ phosphate incorporation into phosphatidylinositol and phosphatidate in chromaffin cells was also observed by Adnan and Hawthorne (1981). Nicotinic stimulation caused smaller and less reproducible effects than muscarinic stimulation (Fisher et al., 1981). The discovery that the initial reaction leading to the phospholipid changes was the phosphodiesteratic cleavage of polyphosphoinositides by phospholipase $\mathrm{C}$, which produces $\mathrm{IP}_{3}$ and $\mathrm{IP}_{2}$ (Berridge et al., 1982; Agranoff et al., 1983), prompted us to reexamine the effects of cholinergic stimulation by investigating the production of inositol phosphates. The specific nicotinic agonist DMPP and the specific muscarinic agonist muscarine each stimulated the

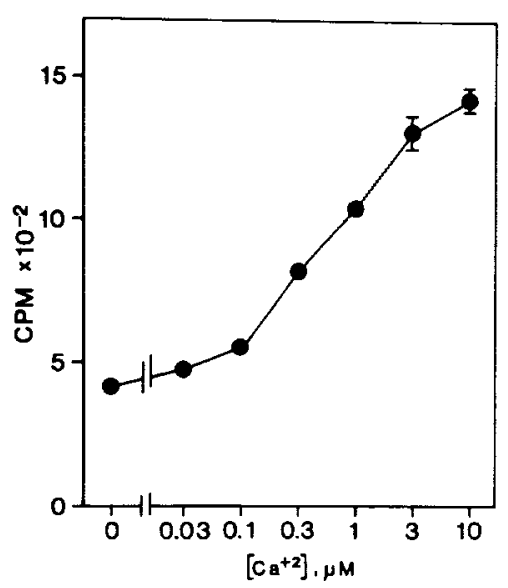

FIG. 7. Effect of $\mathrm{Ca}^{2+}$ on formation of inositol phosphates in digitonin-permeabilized cells. Cells prelabeled for $15 \mathrm{~h}$ with $\left[{ }^{3} \mathrm{H}\right]-$ inositol were incubated in $0 \mathrm{Ca}^{2+} \mathrm{KGEP}$ solution containing $10 \mathrm{mM}$ $\mathrm{LiCl}$ and $20 \mu \mathrm{M}$ digitonin for $7 \mathrm{~min}$. The medium was replaced with KGEP containing $10 \mathrm{mM} \mathrm{LiCl}$ and various concentrations of free $\mathrm{Ca}^{2+}$. After $15 \mathrm{~min}$ the amount of $\left[{ }^{3} \mathrm{H}\right]$ inositol phosphates in the wells was determined. There were four wells/group. formation of inositol phosphates. IP was the predominant species accumulated in response to both agonists. The production of inositol phosphates stimulated by DMPP was blocked by the nicotinic antagonist mecamylamine but not by the muscarinic antagonist atropine. The effects of each agonist were saturable, and together were additive at concentrations that were maximal for the effects of either agonist alone. Thus, nicotinic and muscarinic receptors independently activate phospholipase $\mathrm{C}$ and the production of inositol phosphates.

Activation of phospholipase $\mathrm{C}$ by nicotinic stimulation is not unique to the adrenal medulla. Preganglionic stimulation of the rat superior cervical ganglion produces an increase in $\left[{ }^{32} \mathrm{P}\right]$ phosphatidylinositol labeling that can be blocked with tubocurarine, an antagonist of the postsynaptic nicotinic receptor (Larrabee and Leicht, 1965). The formation of inositol phosphates in the ganglion is also increased by both muscarinic and nicotinic stimulation (Briggs et al., 1985).

\section{Mechanism of phospholipase $\mathrm{C}$ activation by muscarinic and nicotinic receptor activation}

Recent evidence indicates that receptor-induced activation of phospholipase $\mathrm{C}$ may be mediated by a GTP-binding protein (Litosch et al., 1985). The muscarinic receptor probably acts through this mechanism (Evans et al., 1985). In contrast, there is no evidence for a direct coupling of the nicotinic receptor to phospholipase C. Nicotinic stimulation in chromaffin cells results in $\mathrm{Ca}^{2+}$ influx (Douglas, 1975; Holz et al., 1982; Kilpatrick et al., 1982) and a rise in cytosolic $\mathrm{Ca}^{2+}$ (Knight and Kesteven, 1983; Kao and Schneider, 1986). A rise in cytosolic $\mathrm{Ca}^{2+}$ has been implicated in activating phospholipase $\mathrm{C}$ in iris smooth muscle (Akhtar and Abdel-Latif, 1978). The following observations suggest that $\mathrm{Ca}^{2+}$ influx induced by nicotinic stimulation activates phospholipase $C$ in chromaffin cells, whereas the muscarinic receptor acts through a different mechanism: (1) The accumulation of inositol phosphates in response to nicotinic stimulation was strongly inhibited by removal of extracellular $\mathrm{Ca}^{2+}$ and completely inhibited in $\mathrm{Ca}^{2+}$-free medium containing EGTA. The muscarinic effect was less sensitive to inhibition by removal of $\mathrm{Ca}^{2+}$. (2) Increasing the availability of extracellular $\mathrm{Ca}^{2+}$ increased the sensitivity of inositol phosphates production to stimulation by DMPP but not by muscarine. (3) Elevated $\mathrm{K}^{+}$, which causes membrane depolarization and $\mathrm{Ca}^{2+}$ influx without receptor activation, also increased the formation of inositol phosphates. (4) Drugs that block $\mathrm{Ca}^{2+}$ influx inhibited the increased accumulation of inositol phosphates in response to DMPP and elevated $\mathrm{K}^{+}$, but caused little or no inhibition of the response to muscarine. (5) Submicromolar and micromolar $\mathrm{Ca}^{2+}$ directly stimulated the release of inositol phosphates from digitonin-permeabilized chromaffin cells. 


\section{Relationship between the production of inositol phosphates and catecholamine secretion}

The ability of both nicotinic and muscarinic receptor stimulation to activate phospholipase $\mathrm{C}$ is consistent with the involvement of diglyceride and inositol phosphates in secretion induced by the physiological agonist acetylcholine. However, because $\mathrm{Ba}^{2+}$, which is an effective secretagogue, does not cause the accumulation of inositol phosphates and because muscarinic stimulation does not cause secretion from bovine adrenal cells, the phosphodiesteratic cleavage of polyphosphoinositides is neither sufficient nor necessary for exocytosis. Instead, the products of phospholipase $\mathrm{C}$ may modulate exocytosis and other cellular processes as described below.

\section{Diglyceride and the activation of protein kinase $C$}

Activation of protein kinase $C$ by exogenous diglyceride or phorbol esters enhances $\mathrm{Ca}^{2+}$-dependent secretion in intact and permeabilized chromaffin cells (Knight and Baker, 1983; Pocotte et al., 1985; Brocklehurst et al., 1985; Lee and Holz, 1986; TerBush and Holz, 1986). Diglyceride produced by phospholipase $\mathrm{C}$ during cholinergic stimulation may modulate the secretory response to $\mathrm{Ca}^{2+}$ through the activation of protein kinase $C$. Indeed, nicotinic stimulation or exogenous diglyceride causes a significant translocation of protein kinase $\mathrm{C}$ from a soluble to a membranebound form in intact cells (TerBush and Holz, 1986). Because translocation of protein kinase $\mathrm{C}$ is required for activation of the enzyme (Kikkawa et al., 1982, 1983), the data suggest that nicotinic stimulation activates protein kinase $\mathrm{C}$ which would enhance $\mathrm{Ca}^{2+}$ dependent secretion.

Muscarinic stimulation induces little or no protein kinase $\mathrm{C}$ translocation compared to nicotinic stimulation (TerBush and Holz, 1986; TerBush and Holz, manuscript in preparation) in spite of a similar degree of activation of phospholipase $\mathrm{C}$. The translocation and activation of protein kinase $\mathrm{C}$ may require higher cytosolic $\mathrm{Ca}^{2+}$ concentrations than those attained with muscarinic receptor activation (Kao and Schneider, 1985, 1986). Alternatively, it is possible that only nicotinic stimulation results in significant diglyceride accumulation. Indeed, the inability to detect reproducible nicotinic receptor-induced increases in phospholipid turnover (Fisher et al., 1981; Adnan and Hawthorne, 1981) suggests that diglyceride reenters the phosphatidylinositol cycle at a slower rate during nicotinic stimulation than during muscarinic stimulation. Thus, diglyceride accumulation would be greater during nicotinic stimulation.

\section{$\mathrm{IP}_{3}$ and cytosolic $\mathrm{Ca}^{2+}$}

$\mathrm{IP}_{3}$ releases $\mathrm{Ca}^{2+}$ from intracellular stores in a number of cell types including bovine adrenal chromaffin cells (Stoehr et al., 1986). Recently it was demonstrated that muscarinic receptors on bovine chromaffin cells mediate a rise in cytosolic $\mathrm{Ca}^{2+}$ that is independent of extracellular $\mathrm{Ca}^{2+}(\mathrm{KaO}$ and
Schneider, 1985). Intracellular $\mathrm{Ca}^{2+}$ rose from approximately $0.10 \mu M$ to $0.15 \mu M$, which is insufficient to stimulate catecholamine secretion. It is likely that the production of $\mathrm{IP}_{3}$ by muscarinic stimulation demonstrated in the present experiments causes the rise in cytosolic $\mathrm{Ca}^{2+}$.

Nicotinic stimulation causes a much larger rise in cytosolic $\mathrm{Ca}^{2+}$ than muscarinic stimulation (Knight and Kesteven, 1983; Kao and Schneider, 1986). The rise in cytosolic $\mathrm{Ca}^{2+}$ from $0.1 \mu M$ to $1-10 \mu M$ requires extracellular $\mathrm{Ca}^{2+}$ and can be accounted for by $\mathrm{Ca}^{2+}$ influx across the plasma membrane (Holz et al., 1982; Kilpatrick et al., 1982; Kao and Schneider, 1986). Thus, the production of $\left[{ }^{3} \mathrm{H}\right] \mathrm{IP}_{3}$ caused by nicotinic stimulation, which is similar in amount to that caused by muscarinic stimulation, probably contributes minimally to the rise in cytosolic $\mathrm{Ca}^{2+}$ during nicotinic stimulation of catecholamine secretion.

\section{Phospholipase $\mathrm{C}$ and tyrosine hydroxylase phosphorylation and activation}

Tyrosine hydroxylase, the rate-limiting enzyme in catecholamine biosynthesis, is phosphorylated and activated on nicotinic stimulation of chromaffin cells (Haycock et al., 1982; McTigue et al., 1985; Pocotte et al., 1986). Both protein kinase C (Albert et al., 1984; Pocotte and Holz, 1986) and $\mathrm{Ca}^{2+} /$ calmodulin-dependent kinase ${ }^{1}$ (Yamauchi et al., 1981; Vulliet et al., 1984) phosphorylate tyrosine hydroxylase. The finding that nicotinic stimulation activates phospholipase $\mathrm{C}$ raises the possibility that nicotinic effects on tyrosine hydroxylase result, in part, from activation of protein kinase $\mathrm{C}$.

\section{Relationship to previous studies concerning phosphatidylinositol metabolism in chromaffin cells}

After this article was completed it was reported that carbachol, a mixed muscarinic-nicotinic agonist, caused accumulation of inositol phosphates in chromaffin cells (Forsberg et al., 1986). The accumulation was interpreted to result solely from muscarinic stimulation because of the ability of the muscarinic antagonist atropine to inhibit completely carbachol-induced inositol phosphate production whereas the nicotinic antagonist hexamethonium was relatively ineffective. However, at the concentrations of antagonists used (10 $\mu M$ each), atropine inhibits nicotinic receptor-induced catecholamine secretion whereas hexamethonium has little effect (Holz, unpublished observations). Because atropine and hexamethonium were not used at concentrations that specifically block muscarinic and nicotinic receptors, the data from the study are consistent with both nicotinic and muscarinic receptor stimulation causing the production of inositol phosphates.

\footnotetext{
${ }^{1}$ Activation of tyrosine hydroxylase activity by phosphorylation caused by a $\mathrm{Ca}^{2+} /$ calmodulin-dependent protein kinase also requires an activating protein found in rat brain and rat adrenal gland (Yamauchi et al., 1981).
} 
Acknowledgment: We are grateful to Dr. S. K. Fisher for many useful discussions and for his advice concerning the measurement of inositol phosphates, and to Dr. R. Simpson for the kind gift of nifedipine. This work was supported by PHS Grants R01 AM27959 and R01 AM36084. R.W.H. is an Established Investigator of the American Heart Association. D.A.E. was supported by P.H.S. Training Grant T32 GM07767 and by a Lutheran Brotherhood Medical Scientist Scholarship.

\section{REFERENCES}

Adnan N. A. M, and Hawthorne J. N. (1981) Phosphatidylinositol labelling in response to activation of muscarinic receptors in bovine adrenal medulla. $J$. Neurochem. 36, 1858-1860.

Agranoff B. W., Murthy P., and Seguin E. B. (1983) Thrombin-induced phosphodiesteratic cleavage of phosphatidylinositol bisphosphate in human platelets. J. Biol. Chem. 258, 2076-2078.

Akhtar R. A. and Abdel-Latif A. A. (1978) Calcium ion requirement for acetylcholine-stimulated breakdown of triphosphoinositide in rabbit iris smooth muscle. J. Pharmacol. Exp. Ther. 204, 655-668.

Albert K. A., Helmer-Matyjek E., Nairn A. C., Muller T. H., Haycock J. W., Greene L. A., Goldstein M., and Greengard P. (1984) Calcium/phospholipid-dependent protein kinase (protein kinase $C$ ) phosphorylates and activates tyrosine hydroxylase. Proc. Natl. Acad. Sci. USA 81, 7713-7717.

Berridge M. J., Downes C. P., and Hanley M. R. (1982) Lithium amplifies agonist-dependent phosphatidylinositol responses in brain and salivary glands. Biochem. J. 206, 587-595.

Berridge M. J., Downes C. P., and Hanley M. R. (1982) Lithium amplifies agonist-dependent phosphatidyinositol responses in brain and salivary glands. Biochem. J. 206, 587-595.

Berridge M. J., Dawson R. M. C., Downes C. P., Heslop J. P., and Irvine R. F. (1983) Changes in the levels of inositol phosphates after agonist-dependent hydrolysis of membrane phosphoinositides. Biochem. J. 212, 473-482.

Boarder M. R., Marriott D., and Adams M. (1987) Stimulus secretion coupling in cultured chromaffin cells: Dependency on external sodium and on dihydropyridine-sensitive calcium channels. Biochem. Pharmacol. 36, 163-167.

Briggs C. A., Horwitz J., McAfee D. A., Tsymbalov S., and Perlman R. L. (1985) Effects of neuronal activation on inositol phospholipid metabolism in the rat autonomic nervous system. J. Neurochem. 44, 73!-739.

Brocklehurst K. W., Morita K., and Pollard H. B. (1985) Characterization of protein kinase $\mathrm{C}$ and its role in catecholamine secretion from bovine adrenal-medullary cells. Biochem. $J$. 228, 35-42.

Cena V., Nicolas G. P., Sanchez-Garcia P., Kirpekar S. M., and Garcia A. G. (1983) Pharmacological dissection of receptorassociated and voltage-sensitive ionic channels involved in catecholamine release. Neuroscience 10, 1455-1462.

Corcoran J. J. and Kirshner N. (1983) Inhibition of calcium uptake, sodium uptake, and catecholamine secretion by methoxyverapamil (D600) in primary cultures of adrenal medulla cells. J. Neurochem. 40, 1106-1109.

Douglas W. W. (1975) Secretory control of adrenal medullary section: membrane and ionic events in stimulus-secretion coupling, in Handbook of Physiology Endocrinology, Sect. 7. Vol. 6 (Blaschko H., Sayers G., and Smith A. D., eds), pp. 367-388. American Physiological Society, Washington DC.

Dunn L. A. and Holz R. W. (1983) Catecholamine secretion from digitonin-treated adrenal medullary chromaffin cells. $J$. Biol. Chem. 258, 4989-4993.

Evans T., Hepler J. R., Masters S. B., Brown J. H., and Harden T. K. (1985) Guanine nucleotide regulation of agonist binding to muscarinic cholinergic receptors. Biochem. $J$. 232, $751-757$.
Fisher S. K., Holz R. W., and Agranoff B. W. (1981) Muscarinic receptors in chromaffin cell cultures mediate enhanced phospholipid labelling but not catecholamine secretion. J. Neurochem. 37, 491-497.

Forsberg E. J., Rojas E., and Pollard H. B. (1986) Muscarinic receptor enhancement of nicotine-induced catecholamine secretion may be mediated by phosphoinositide metabolism in bovine adrenal chromafin cells. J. Biol. Chem. 261, $4915-4920$.

Haycock J. W., Meligeni J. A., Bennett W. F., and Waymire J. C. (1982) Phosphorylation and activation of tyrosine hydroxylase mediate the acetylcholine-induced increase in catecholamine biosynthesis in adrenal chromaffin cells. J. Biol. Chem. 257, $12641-12648$.

Holz R. W. and Senter R. A. (1985) Plasma membrane and chromaffin granule characteristics in digitonin-treated chromaffin cells. $J$. Neurochem. 45, 1548-1557.

Holz R. W., Senter R. A., and Frye R. A. (1982) Relationship between $\mathrm{Ca}^{2+}$ uptake and catecholamine secretion in primary dissociated cultures of adrenal medulla. $J$. Neurochem. 39, 635-646.

Horwitz J., Tsymbalov S., and Perlman R. L. (1984) Muscarine increases tyrosine 3-monooxygenase activity and phospholipid metabolism in the superior cervical ganglion of the rat. $J$. Pharmacol Exp. Ther. 229, 577-582.

Kao L.-S. and Schneider A. S. (1985) Muscarinic receptors on bovine chromaffin cells mediate a rise in cytosolic calcium that is independent of extracellular calcium. J. Biol. Chem. 260, 2019-2022.

Kao L.-S. and Schneider A. S. (1986) Calcium mobilization and catecholamine secretion in adrenal chromaffin cells. J. Biol. Chem. 261, 4881-4888.

Kikkawa U., Takai Y., Minakuchi R., Inohara S., and Nishizuka Y. (1982) Calcium-activated phospholipid-dependent protein kinase from rat brain. J. Biol. Chem. 257, 13341-13348.

Kikkawa U., Takai Y., Tanaka Y., Miyake R., and Nishizuka Y. (1983) Protein kinase $C$ as a possible receptor protein of tumor-promoting phorbol esters. J. Biol. Chem. 258, 1144211445.

Kilpatrick D. L., Slepetis R. J., Corcoran J. J., and Kirshner N. (1982) Calcium uptake and catecholamine secretion by cultured bovine adrenal medulla cells. $J$. Neurochem. 38, $427-435$.

Knight D. E. and Baker P. F. (1983) The phorbol ester TPA increases the affinity of exocytosis for calcium in "leaky" adrenal medullary cells. FEBS Lett. 160, 98-100.

Knight D. E. and Kesteven N. T. (1983) Evoked transient intracellular free $\mathrm{Ca}^{2+}$ changes and secretion in isolated bovine adrenal medullary cells. Proc. $R$. Soc. Lond. [B] 218, 177-199.

Larrabee M. G. and Leicht W. S. (1965) Metabolism of phosphatidyl inositol and other lipids in active neurones of sympathetic ganglia and other peripheral nervous tissues. The site of the inositide effect. J. Neurochem. 12, 1-13.

Lee S. A. and Holz R. W. (1986) Protein phosphorylation and secretion in digitonin- permeabilized adrenal chromaffin cells: effects of micromolar $\mathrm{Ca}^{2+}$ phorbol esters, and diacylglycerol. J. Biol. Chem. 261, 17089-17098.

Litosch I., Wallis C., and Fain J. N. (1985) 5-Hydroxytryptamine stimulates inositol phosphate production in a cell-free system from blowfly salivary glands. J. Biol. Chem. 260, 5464-5471.

McTigue M., Cremins J., and Halegoua S. (1985) Nerve growth factor and other agents mediate phosphorylation and activation of tyrosine hydroxylase. J. Biol. Chem. 260, 9047-9056.

Nishizuka Y. (1984) The role of protein kinase C in cell surface signal transduction and tumour promotion. Nature 308, 693-698.

Pinto J. E. B. and Trifaro J. M. (1976) The different effects of D-600 (methoxyverapamil) on the release of adrenal catecholamines induced by acetylcholine, high potassium, or sodium. Br. J. Pharmacol. 57, 127-132.

Pocotte S. L. and Holz R. W. (1986) Effects of phorbol ester on tyrosine hydroxylase phosphorylation and activation in cul- 
tured bovine adrenal chromaffin cells. J. Biol. Chem. 261, 1873-1877.

Pocotte S. L., Frye R. A., Senter R. A., TerBush D. R., Lee S. A., and Holz R. W. (1985) Effects of phorbol ester on catecholamine secretion and protein phosphorylation in adrenal medullary cell cultures. Proc. Natl. Acad. Sci. USA 82, 930-934.

Pocotte S. L., Holz R. W., and Ueda T. (1986) Cholinergic receptor-mediated phosphorylation and activation of tyrosine hydroxylase in cultured bovine adrenal chromaffin cells. $J$. Neurochem. 46, 610-622.

Portzehl H., Caldwell P. C., and Reugg J. C. (1964) The dependence of contraction and relaxation of muscle fibers from the crab Maia squinado on the internal concentration of free calcium ions. Biochim. Biophys. Acta 79, 581-591.

Putney J. W., Burgess G. M., Halenda S. P., McKinney J. S., and Rubin R. P. (1983) Effects of secretagogues on [ $\left.{ }^{32} P\right]$ phosphatidylinositol 4,5-bisphosphate metabolism in the exocrine pancreas. Biochem. J. 212, 483-488.

Stoehr S. J., Smolen J. E., Holz R. W., and Agranoff B. W. (1986) Inositol trisphosphate mobilizes intracellular calcium in permeabilized adrenal chromaffin cells. $J$. Neurochem. 46, 637-640.

TerBush D. R. and Holz R. W. (1986) Effects of phorbol esters, diacylglycerol and cholinergic agonists on the subcellular dis- tribution of protein kinase $\mathrm{C}$ in intact or digitonin-permeabilized adrenal chromaffin cells. J. Biol. Chem. 261, 1709917106.

Trifaro J. M. (1969) Phospholipid metabolism and adrenal medullary activity I. Effect of acetylcholine on tissue uptake and incorporation of orthophosphate- ${ }^{32} \mathrm{P}$ into nucleotides and phospholipids of bovine adrenal medullae. Mol. Pharmacol. 5, 382-393.

Vulliet P. R., Woodgett J. R., and Cohen P. (1984) Phosphorylation of tyrosine hydroxylase by calmodulin-dependent multiprotein kinase. J. Biol. Chem. 259, 13680-13683.

Waymire J. C., Bennett W. F., Boehme R., Hanteins L., GilmerWaymire K., and Haycock J. (1983) Bovine adrenal chromaffin cells: high-yield purification and viability in suspension culture. J. Neurosci. Methods 7, 329-351.

Wilson S. P. and Kirshner N. (1977) The acetylcholine receptor of the adrenal medulla. $J$. Neurochem. 28, 687-695.

Wilson S. P. and Kirshner N. (1983) Calcium-evoked secretion from digitonin-permeabilized adrenal medullary chromaffin cells. J. Biol. Chem. 258, 4994-5000.

Yamauchi T., Nakata H., and Fujisawa H. (1981) A new activator protein that activates tryptophan 5-monooxygenase and tyrosine 3-monooxygenase in the presence of $\mathrm{Ca}^{2+}$, calmodulindependent protein kinase. J. Biol. Chem. 256, 5404-5409. 